\title{
Sustaining Sustainability
}

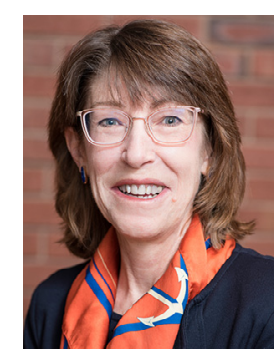

While JNEB has a long history of publishing articles related to sustainability, this is the first full issue devoted to the topic. In searching the jneb.org site, I find hundreds of articles related to sustainability. This is incredible work. Thank you, authors!

I found the 1989 Report by Herrin and Gussow ${ }^{1}$ very interesting. They provide an overview of how one can analyze a state's local foods to explore the ability to eat locally. Montana's choices were limited, especially in the winter. This may not be surprising, the detail the authors provide for their evaluation could be very instructive.

More recently, Jung et $\mathrm{al}^{2}$ applied qualitative methods with university students to identify beliefs about local food consumption. They found the students had several beliefs about the advantages of local food consumption, such as health benefits, less processing, more freshness, and supporting the local community. The disadvantages included a perception of less variety and higher costs. The authors provide some insights for education, as well as campus administration, for enhancing the purchase of local foods.
In a large $(\mathrm{n}=\sim 3000)$ study, Racine et $\mathrm{al}^{3}$ examined factors associated with buying local produce in North Carolina. With close to half of the families purchasing local produce about once per month, the authors found that those from lower incomes and living in rural areas were more likely to purchase local produce. Those whose habit was to eat many fruits and vegetables and those with a child in poor health were also more likely to buy local produce. Interestingly, Smith and Miller ${ }^{4}$ found neither rural nor urban Minnesotans offering comments on local foods or sustainability during interviews across 8 counties about the food systems in their areas. This work was completed 10 years ago, so it may or may not be as relevant today. Indeed, an early study by Wilkins et $\mathrm{al}^{5}$ found that while most college students had heard of the term "local foods," only about one fourth reported using the term themselves in 2000.

This issue contains a wider look at sustainability, including the impact of food insecurity and food assistance programs, new perspectives on food waste, and the importance of food skills. Sustainability is a term that has broad arms and can mean many different things to different people. A good overview of this was published by JNEB in 2019 as the position of the Society for Nutrition Education and Behavior outlining the importance of including sustainability in dietary guidance. ${ }^{6}$ Although the terms "local" and "sustainability" are relatively new, this concept will be sustained as we all continue to care for ourselves and the planet.

\section{Karen Chapman-Novakofski $P h D, R D N$ Editor-in-Chief}

\section{REFERENCES}

1. Herrin M, Gussow JD. Designing a sustainable regional diet. I Nutr Educ. 1989;21:270-275.

2. Jung SE, Shin YH, Dougherty R. A multi theory-based investigation of college students' underlying beliefs about local food consumption. J Nutr Educ Behav. 2020;52:907-917.

3. Racine EF, Mumford EA, Laditka SB, Lowe AE. Understanding characteristics of families who buy local produce. J Nutr Educ Behav. 2013;45:30-38.

4. Smith C, Miller H. Accessing the food systems in urban and rural Minnesotan communities. J Nutr Educ Behav. 2011;43: 492-504

5. Wilkins JL, Bowdish E, Sobal J. University student perceptions of seasonal and local foods. J Nutr Ed. 2000;32:261-268.

6. Rose D, Heller MC, Roberto CA. Position of the society for nutrition education and behavior: the importance of including environmental sustainability in dietary guidance. J Nutr Educ Behav. 2019;51:3-15.e1. 